\title{
Lærerperspektiver på inklusion i matematik og dansk
}

\author{
Laura Emtoft, lektor ph.d, Absalon, Ime@pha.dk \\ Lise Overgaard Nielsen, lektor, Absalon, lon@pha.dk \\ Stine Dunkan Gents, lektor, Absalon, stdh@pha.dk \\ Helle Eeg, lektor, Absalon, Heee@pha.dk
}

\begin{abstract}
Resumé
Artiklen undersøger lærernes opfattelse af forholdet mellem inklusion og fagdidaktiske forståelser i matematik og dansk. Sammenhængen mellem inklusion og fagdidaktik er kompleks og underbelyst i forskningen, og artiklen stiller netop skarpt på, at inklusion indeholder både en fagdidaktisk og en social dimension. Analysen af datamaterialet peger på tre grundperspektiver, som beskriver lærernes måde at forstå inklusion og faglighed på: det enstrengede lærerperspektiv, det nuancerede lærerperspektiv og det mangefacetterede lærerperspektiv. Artiklen sandsynliggør, at de lærere, der lykkes bedst med at inkludere elever med særlige behov, er de lærere, som både kan faget i dybden og i bredden, og som er i stand til at justere undervisningen løbende.
\end{abstract}

Nøgleord: inklusion, fagdidaktik, danskfaget, matematikfaget

\begin{abstract}
The article explores teachers' understanding of inclusion in Mathematics and Danish. The relationship between inclusion and professionalism is complex, the article emphasizes that inclusion contains both a professional and a social dimension. The analysis of the data suggests three basic perspectives of teachers: the one-sided perspective, the nuanced perspective and the multifaceted perspective. The article show how teachers seem to have different views of inclusion and professionalism, which might result in different opportunities for student participation. Teachers, who professionally and socially succeed best in managing students with special needs, are those who are able to adjust their teaching techniques continuously.
\end{abstract}

Keywords: inclusion, professionalism, mathematics, literacy

Inklusion har i forskellige variationer længe været en del af dansk skolepraksis. Politisk er der i 2012 blevet foretaget omfattende lovændringer, der har haft til hensigt at skabe mere inkluderende skolemiljøer i folkeskolen (Undervisningsministeriet, 2012; Den Danske Regering, 2013). Omstillingen til øget inklusion har ikke været uden udfordringer for lærere og elever. 
Kvantitative undersøgelser (Amillion, 2015; Jørgensen et al., 2016) viser, at elever, der er tilbageført fra specialklasser eller specialskoler, samt elever, der modtager støtte i almenskolen, trives lidt dårligere end de øvrige elever. Samtidig er deres sociale og faglige deltagelse også lidt lavere end de øvrige elevers.

Elevernes dagligdag i skolen er struktureret omkring fag. De særlige faglige udfordringer, som skolens forskellige fag rummer, og de fagdidaktiske forståelser, som lærerne praktiserer, synliggør elevernes udfordringer. Det gælder ikke kun for elever med særlige behov, men alle elever.

Artiklen undersøger lærernes forståelse af deres praksis med fagdidaktik og inklusion, og hvilken betydning det får for elevernes mulighed for deltagelse og inklusion. På baggrund af den empiriske dataindsamling og analyse præsenterer artiklen tre lærerperspektiver, der beskriver lærernes måde at italesætte og forstå inklusion og fagdidaktik på: det enstrengede lærerperspektiv, det nuancerede lærerperspektiv og det mangefacetterede lærerperspektiv. Analysen og fundene diskuteres efterfølgende.

\section{Forskningslandskabet}

Inklusionsforskning betragter læreres praksis med inklusion ud fra tre forskellige perspektiver: et klasserums-, et skolekulturs- og et institutionsperspektiv. Inden for klasserumsperspektivet aktualiserede Susan Tetler (2000) med sin afhandling Den inkluderende skole inklusionsdebatten i Danmark. Tetler (2000) fokuserede på de enkelte læreres kompetencer i forhold til undervisningsdifferentiering, dels fordi hun finder, at det er vanskeligt for mange lærere, og dels fordi lærerne i de tilfælde, hvor det lykkes at differentiere, muliggør både social og faglig deltagelse for de elever, der er i udsatte positioner. I lighed hermed finder Mette Molbæk (2016), at lærerne er optaget af at sikre deltagelse for alle elever, men at dette arbejde er komplekst og dilemmafyldt. Begge peger på rammesætning, relationer og didaktik som væsentlige dimensioner i inkluderende klasse- og læringsledelse og dermed som kompetencer, det er væsentligt for lærerne at udvikle. Et lignende fund gør Christian Quvang (2009).

Ud fra et skolekulturperspektiv undersøger Camilla Dyssegård (2009) inkluderende skolekultur og peger på, at den enkelte lærer ikke kan løfte opgaven alene, og at det er helt afgørende for, om inklusion kan lykkes, at skolens aktører deler en fælles vision. Inden for samme perspektiv undersøger Anne Morin (2008) elevers deltagelse på tværs af almene og specialpæ- 
dagogiske læringsarenaer i skolen. Morins pointe er, at så længe elevernes vanskeligheder betragtes ud fra et individperspektiv med fokus på læring som individuel proces, vil både professionelle og elever opleve afmagt og mangel på handlemuligheder. Disse to studier anlægger et perspektiv på inkluderende praksis, som er væsentligt i forhold til at forstå læreres praksis med inklusion ud fra en bredere forståelse af kompetencer. Dette vil sige en bredere forståelse, hvor lærernes kompetencer til at indgå i inklusionsprocesser ikke isoleres til den enkelte lærers kompetencer, men ses i relation til den samlede mængde af kompetencer på en skole, som er afhængig af skolekulturens forståelse af elever med særlige behov.

Der er som udgangspunkt ikke en diskrepans mellem det førnævnte klasserumsperspektiv og et skolekulturperspektiv, men hvor klasserumsperspektivet har fokus på mikroprocesser, tilbyder skolekulturperspektivet en bredere forståelse.

Helene Ratner (2012) undersøger i et institutionsperspektiv, hvordan refleksion spiller en rolle i forventninger til lederes og læreres praksis. Ratner (2012) fremhæver, at lærere og lederes hverdag i skoler, der arbejder med øget inklusion, er præget af dilemmaer, og at det, der udpeges som den centrale kompetence til at opnå øget inklusion, er lærerens evne til refleksion. Ud fra samme perspektiv undersøger Rasmus Alenkær (2010), hvorvidt akt-vejlederen og almenlærerne kan facilitere inklusion. Thomas Thyrring Engsig (2016) undersøger støtteforanstaltninger i skolen og peger på, at støttelæreres og almenlæreres evne til at kommunikere med hinanden er væsentlige for støttens kvalitet og inklusionspotentiale.

Den fagdidaktiske forskning i fagene dansk og matematik med et inklusionsperspektiv er kun i sin vorden. Inden for danskfaget er forskningen hovedsageligt fokuseret på elever med danskfaglige vanskeligheder: dysleksi (Gellert et al., 2018), tosprogsproblemer (Laursen, 2011) og læsevanskelighedsproblemer (Svendsen 2017; Grimsæth \& Holgersen 2015). Fokus er på faglige mangler hos eleven og afledt deraf på, hvordan forskellige kompenserende tiltag som fx IT (Svendsen 2016) kan understøtte elevens faglige deltagelse. Inden for matematikdidaktisk forskning ses den samme tendens, med forskning, der retter sig mod elever med specifikke matematikvanskeligheder, hvor forklaringer af neurologisk, psykologisk, sociologisk og didaktisk art beskrives (Engström, 2003; Sjöberg, 2006; Geary, 2004) eller med et snævert fokus på dyskalkuli (Adler, 2005; Butterworth, 2003). Derudover er der kategoriseringer af forskellige typer af matematikvanskeligheder (Ostad, 2008; Lunde, 2010). Forskningsprojektet Inklusionsbestræbelser 
i matematikundervisningen (Schmidt, 2015) fokuserer ligeledes på elever med matematikvanskeligheder og forsøger at koble almen pædagogik med fagdidaktik. Fokus bliver dermed flyttet fra det kompenserende individperspektiv til et mere fagdidaktisk og kontekstbaseret perspektiv.

Forskningen inden for lærernes fagdidaktiske forståelse er typisk præget af normative bud og analyser af styringsdokumenter (Fælles Mål, vejledninger og bekendtgørelser) (Hansen, 2015; Hansen, 2012; Ernest, 2000). Empirisk forskning i matematiklærerens beliefs (Askew et al., 1997; Wilson \& Cooney, 2002; Lloyd, 2002; Llinares, 2002; Lerman, 2002) og en beskrivelse af matematiklæreres pedagogical content knowledge (Shulman, 1986; Ball et al., 2008; Rowland et al., 2005) ses internationalt, men denne forskning kobles ikke til inklusion.

Sammenfattende for forskningslandskabet er, at den brede forskningen i inklusion og den specifikke forskning i dansk- og matematikvanskeligheder er adskilte forskningsfelter. Derudover kobles lærerens fagdidaktiske forståelse i mindre grad med inklusionsforskningen. Det er netop dette felt, som denne artikel undersøger.

\section{Metode}

Undersøgelsen bygger på observationsbaserede interviews (Kampmann, 2017). Det observationsbaserede interview som metode tager udgangspunkt i en række konkrete observationer, som danner basis for interviewet. Observationer foretages i lærernes undervisningspraksis og bliver dermed omdrejningspunktet for lærerens refleksion i interviewet. Observationerne foretages hen over flere dage og undervisningstimer. Efterfølgende udvælger forskeren flere sekvenser af den observerede praksis, som gøres til udgangspunkt for interviewet. Metoden kræver, at forskeren har været til stede i praksis i et omfang, der muliggør en indkredsning af de situationer, der kan danne afsæt for interviewene (Kampmann, 2017; Knudsen et al., 2009). Det observationsbaserede interview er udviklet i forbindelse med interviews af børn.

Det forskningsbaserede interview giver forskeren mulighed for at samtale med børnene om helt konkrete oplevelser, hvor begge har været til stede. Forskeren kan ligeledes spørge ind til dele af situationen, som barnet ikke fokuserer på, men som observationerne synes at vise er vigtige. Den grundlæggende udfordring ved interview som metode er, at der ofte er en diskrepans mellem, hvad den interviewede siger, og hvad den interviewede gør. Selv om lærerne i dette projekt ikke er børn og sagtens kan abstrahere, 
er alle mennesker biased i forhold til egen praksis. I praksis i det observationsbaserede interview betyder det, at forskeren dels kan spørge ind til uoverensstemmelser mellem udtalelser og den observerede praksis og dels kan spørge ind til konkrete hændelser og motiver, grunde og forståelser af disse. Disse forståelser relaterer sig til den konkrete observation, men bevæger sig også omkring mere overordnede og grundlæggende forståelser af praksis. Dermed udgør observationerne i sig selv ikke det empiriske grundlag, men interviewene, som er informeret af og centreret om observationerne, kommer til at udgøre det empiriske materiale, som gøres til genstand for analyse. Formålet med at vælge denne metode var netop at få en indsigt i lærernes egen forståelse af inklusion og fagdidaktik i relation til deres egen konkrete praksis. Ratner (2012) og Morin (2008) fremhæver netop betydningen af lærernes refleksionsevne og perspektiv på inklusion som værende afgørende faktorer for øget inklusion.

Vi har foretaget ca. 90 timers observation af henholdsvis dansk- og matematikundervisningen $\mathrm{i}$ ti forskellige klasser på otte forskellige skoler. Alle skolerne i udkantskommuner i Region Sjælland. Lederne udvalgte lærere til deltagelse i projektet ud fra kriterier om, at de var linjefagsuddannede i dansk eller matematik, underviste på mellemtrinnet og havde tid og lyst til at deltage. Disse observationer har dannet grundlag for ti lærerinterviews. I forbindelse med valget af observerede situationer som basis for interviewene valgte vi at fokusere på mønstre i undervisningspraksis og afvigelser derfra. Derudover fokuserede vi på observerede situationer med elever med særlige behov. På den baggrund blev dels lærernes fagdidaktiske refleksioner over undervisningssekvenser og dels deres overvejelser over deres konkrete inklusionspraksis omdrejningspunkter for det semistrukturerede interview. Interviewene er efterfølgende blevet kodet i forhold til kategorierne: inklusionsperspektiv, fagdidaktisk forståelse og almen pædagogiske refleksioner.

\section{Analysestrategi}

Inden vi kommer ind på kendetegnene ved de tre fremanalyserede lærerperspektiver: det enstrengede lærerperspektiv, det nuancerede lærerperspektiv og det mangefacetterede lærerperspektiv, vil vi fokusere på det teoretiske analyseredskab, vi har anvendt til kategoriseringen af vores empiriske data. Analysen tager udgangspunkt i en praksisteoretisk position. Denne position er kendetegnet ved et forsøg på at sammentænke elementer i eksisterende sociologisk teori til et nyt analytisk perspektiv på konstituering og kondi- 
tionering af mikroprocesser i det sociale liv. Analytisk tilbyder den praksisteoretiske position et bredt perspektiv på, hvad praksis er konstitueret af. I denne forståelse indgår både de ting, der gøres og produceres, udtalelser, tanker, forståelser, viden, engagement og artefakter som delelementer i praksis (Halkier \& Jensen, 2008). Dermed er den praksis, vi analyserer, både den praksis, som observeres, som danner grundlag for interviewet, og den måde, lærerne taler om og forstår den praksis.

Med begrebet 'holistisk fagbegreb' (Bundsgaard \& Fougt, 2017) forstår Bundsgaard \& Fougt et fagbegreb, der kan rumme både det særligt faglige, der er synligt for alle, fx matematikkens regningsarter eller danskfagets grammatiske betegnelser, og det bagvedliggende verdenssyn, som legitimerer og definerer, hvad faget mener er væsentligt at beskæftige sig med. Forskellige fagligheder har forskellige måder at se, forstå, analysere og tolke verden på. Bundsgaard \& Fougt opererer i alt med fem dimensioner i det holistiske fagbegreb: 1) et perspektiv - som vedrører, hvordan faget ser verden, hvordan faget forstår og taler om den, 2) en interesse - som handler om værdier og motiver, 3) en social konstellation - hvilken rolle har man, hvilke andre systemer indgår man i, og hvordan kommunikerer man i fagligheden? 4) en systematisk tilgang til verden - en metodik, man arbejder ud fra, 5) viden, fagsprog og procedurer. De fem dimensioner er ikke ordnet i en bestemt taksonomi, men er delelementer, der tilsammen udgør en persons fagdidaktiske forståelse. Det holistiske fagbegreb giver os en mulighed for at analysere to meget forskellige fagdidaktiske traditioner (dansk og matematik) ud fra et fælles analytisk blik. Derudover tilbyder det holistiske fagbegreb et situationsdidaktisk fundament, som omfavner lærerens praksis og lærerens fagdidaktiske refleksioner.

Bundsgaard \& Fougts holistiske fagbegreb forholder sig dog ikke til inklusion, og derfor inddrager vi Tetlers (2009) perspektiv på særlige behov. Tetler (2009) peger på, at der er tre overordnede perspektiver, som dominerer både i forskningen og i lærernes forståelse af, hvordan man skal forstå elever med særlige behov: individuelt, socialt eller relationelt. Alt efter hvilket perspektiv man arbejder ud fra, vil man være tilbøjelig til at vælge en bestemt fremgangsmåde over for elever med særlige behov. Arbejder man ud fra et individperspektiv, vil de særlige behov også skulle løses individuelt, typisk med udgangspunkt i en diagnose. I et socialt perspektiv vil man derimod se de særlige behov som samfundsskabte. Endelig vil man i et relationelt perspektiv se på relationen mellem den enkelte elev og dennes omgivelser. Her vil indsatsen rette sig mod både individ og relation, hvilket peger i en 
mere reelt inkluderende retning. Vores blik på inklusion er funderet i et relationelt perspektiv på særlige behov. Dette betyder, at vi er optaget af, hvilke deltagelsesmuligheder læringskonteksten skaber for den enkelte elev i en kompleks situation, der er sammenvævet af social og faglig praksis.

\section{Empirisk blik på lærerens forståelse af inklusion og fag}

Igennem det analytiske arbejde trådte der forskellige mønstre frem, hvorpå lærerne forholder sig til deres praksis med fagdidaktik og inklusion. Disse mønstre har vi sammenfattet $\mathrm{i}$ tre forskellige lærerperspektiver på inklusion og fagdidaktik. De tre lærerperspektiver er ikke ligeværdige i forhold til at håndtere inklusion, men udgør en progression i forhold til elevernes muligheder for at blive inkluderet og udvikle sig fagligt. Derved kommer de til at fremstå som en taksonomi, der indplacerer lærerne på en skala fra mindre til mere kompetent, som for eksempel hos Dreyfus (Dreyfus \& Dreyfus, 1986). Med baggrund i vores analysestrategiske perspektiv har vi netop valgt at arbejde med perspektiver som udgangspunkt for et situeret blik, frem for mere statiske kategorier. Dette tydeliggør, at lærerpraksis er kompleks og emergent, og at det, som udgør ét lærerperspektiv i en klasse i ét fag, kan se væsentligt anderledes ud med samme lærer på et andet tidspunkt og med andre børn og fag. Det betyder, at der principielt er tale om en vifte af måder, hvorpå lærerne forholder sig til inklusion og fagdidaktik. Der er dog ikke noget i datamaterialet, der tyder på, at lærerne ændrede deres perspektiver på fagdidaktik og inklusion ud fra de observerede situationer, vi inddrog $\mathrm{i}$ interviewet. De tre perspektiver må derfor forstås med det forbehold, der ligger $i$ at lave en kompleksitetsreducering, der er begrænset af de observationer, vi har foretaget, og efterfølgende interviews. Igennem fremskrivningen af de tre perspektiver vil vi gerne medvirke til at styrke en tættere forbindelse mellem det fagdidaktiske og det inklusionsdidaktiske i lærerprofessionen, og ikke til en kategorisering af lærere eller praksis.

\section{Det enstrengede lærerperspektiv}

I forhold til Bundsgaard \& Fougts (2017) faglighedsdimensioner er det kendetegnende for det enstrengede lærerperspektiv, at lærerne har et ganske smalt fagdidaktisk repertoire (systematik). Undervisningens systematik ligger i en fastlagt form, hvor læreren introducerer, og eleverne løser opgaver. Dermed er det lærerens opgave at sørge for, at eleverne får mulighed for 
at Øve sig, og elevernes opgave er at øve sig. Som en lærer siger: "Vi laver al indlæringen, og så tager vi det en tur til, når man har ca. et kvart år tilbage" (matematiklærer). Denne ensformighed i dels de observerede didaktiske mønstre og dels lærerens refleksion derover peger mod, at disse læreres almendidaktiske og fagdidaktiske overvejelser er begrænsede. De udtrykker ikke overvejelser om, hvordan undervisningsformen kan varieres alt efter fagligt fokus, og det var meget svært at finde brud på det didaktiske mønster i observationerne at interviewe lærerne om. Det faglige arbejde er således centreret omkring færdighedstræning, hvor et anvendelses- og kompetenceperspektiv på faget er helt fraværende.

Lærerne anvender et fagsprog, der har fokus på konkrete faglige områder eller konkrete elever, hvor procedurer, opgaver og brugen af artefakter har den samme form i størstedelen af deres undervisning (fagsprog/viden). Som en af lærerne udtrykker det: “Tit skifter vi mellem, så skal der laves færdighedsregning, nogle andre træningsopgaver, opgaver i bogen, og det er sådan en fast rutine, vi sådan mere eller mindre kører. Fordi de lidt har brug for den der struktur" (matematiklærer).

Lærerne i dette perspektiv ser ikke sig selv som en del af et større system, men refererer primært til sig selv og andre tætte lærerkollegaer på skolen. De er privatpraktiserende (Albrechtsen, 2016) og begrunder ikke deres praksis i relation til skolens fælles beslutninger, teambeslutninger, skolepolitiske dokumenter eller Fælles Mål. De refererer i stedet til sig selv og egne normative erfaringer af, hvad der virker. Desuden er lærernes interesse (Bundsgaard \& Fougt, 2017) at afvikle undervisningen med stram styring for at minimere uro: "Den her klasse fungerer rigtig godt med en streng lærerstyring" (dansklærer). Og en anden lærer: "[...] men de skal stadig have en snert af hold-kæft-ark, hvor du sidder ned og laver noget. De må ikke få for løse opgaver. Det forstår de ikke. Det kan de ikke" (matematiklærer).

Helt overordnet kan man sige, at disse læreres faglige perspektiv er en betoning af basale færdigheder, og at færdighederne bedst læres gennem gentagne øvelser. Netop gentagne øvelser som det observerede omdrejningspunkt fylder forholdsvis meget i vores interviews. Eksempler på dette er: "Der er nogle, der stadig er usikre på ordklasserne, selvom det er noget, vi terper hele tiden" (dansklærer), og "Jeg ved jo godt, at det hverken er fint eller moderne, men jeg er rigtig stor tilhænger af, at nogle ting, det kan man, og det har man terpet, til man kan. Og de kan komme med alle deres teser og alting. De børn, der halter mest i matematik, det er dem, der ikke har lært det grundlæggende" (matematiklærer). 
Dette lærerperspektiv udtrykker et individuelt syn på læring og elevernes udvikling, som afspejler sig i måden, lærerne taler om elever med særlige behov. Til konkrete spørgsmål baseret på observationerne af enkelte elevers manglende deltagelse udtrykker de, at problemet er en fejl eller mangel i det enkelte barn, der gør, at barnet ikke kan lære det faglige stof. Lærerne udtrykker ikke overvejelser om læringskontekstens betydning, som fx undervisningsformen og fagdidaktikken, der gør, at det bliver vanskeligt for barnet at tilegne sig stoffet. Dette mangelsyn, som følger af et individsyn (Tetler, 2009) på særlige behov, træder særligt tydeligt igennem hos disse lærere. Enten sendes eleverne ud af klassen til kompenserende undervisning, som en lærer udtrykker det: “Der er fem, som har det svært, som jeg har indstillet til ekstra her [...] de har svært ved selv de helt grundlæggende ting [...] selvom de selvfølgelig har hørt det mange gange" (matematiklærer), eller eleverne må selv finde veje til at kompensere for manglende læring: “På et eller andet tidspunkt bliver jeg også nødt til at melde ud, at nu kan I det, og jer, der ikke kan det, I kommer altså til at træne det hjemme, for vi har ikke tid til at blive ved" (matematiklærer). Det betyder, at de elever, som ikke har lært det tiltænkte, og som sandsynligvis har brug for hjælp og støtte til at tilegne sig det faglige stof, overgives ansvaret for deres læring, fordi de ikke kan lære det på den måde, som læreren har planlagt, hvilket også kom frem som et mønster i observationerne bag interviewet.

\section{Det nuancerede lærerperspektiv}

Det andet perspektiv, vi ser i vores datamateriale, er karakteriseret ved at have et mere nuanceret fagdidaktisk perspektiv end det enstrengede perspektiv, da der kan fremanalyseres flere dimensioner af Bundsgaard \& Fougts faglighedsbegreb, dog uden at perspektivet er stærkt funderet i nogen af dem. Det er kendetegnende for lærere, der udtrykker dette perspektiv, at de har et større didaktisk repertoire (systematik) end inden for det enstrengede perspektiv. Dette ses ved, at de i højere grad giver udtryk for, at de varierer arbejdsformerne, og de forholder sig til, at der kan være flere måder at gå til det faglige stof på, hvilket også var kendetegnende ved observationerne. Lærerne fortæller om forskellige variationsmønstre i deres undervisningsform, både almendidaktisk, ved fx at veksle mellem forskellige organiseringsmetoder som klasseundervisning, gruppe- eller pararbejde, og fagdidaktisk, fx genreforløb, matematik i hverdagen og sta- 
vetræning. Lærerne overvejer dermed, hvilke elever der vil profitere af at arbejde sammen med hinanden, og i hvilken organiseringsform.

Italesættelsen af det didaktiske repertoire varierer en hel del mellem lærere, der er orienteret mod dette perspektiv, men fælles for dem er, at de begrunder de valgte undervisningsformer i differentieringsmuligheder i undervisningen. De genkomne observerede undervisningssekvenser, som blev omdrejningspunktet for interviewene, var præget af en større grad af variation end observeret i det enstrengede perspektiv. Hvor det i observationerne, der lå til grund for interviewet hos nogle lærere i det enstrengede perspektiv, var svært at finde brud på det didaktiske mønster, så var der her flere variationer, og mønsteret bestod ikke af mangel på variation, men af fravær af differentiering og løbende justering på elevniveau. Mønsteret bestod altså nærmere i, at alle elever arbejdede med det samme på samme tid med ens deadlines. Lærere inden for det nuancerede perspektiv udtrykker en oplevelse af at komme til kort i forhold til fagdidaktiske differentieringsstrategier. De fortæller, at de som udgangspunkt anvender et læremiddel til at strukturere deres undervisning. I matematik typisk én grundbog, hvor det i dansk som regel er flere - alt efter det faglige fokus. Den faglige differentiering består i at enten øge eller sænke mængden af opgaver, som eleverne skal lave.

Lærerne italesætter faget spiralisk, hvormed man vender tilbage til tidligere indhold og bygger ovenpå for at nuancere elevernes forståelse (viden, fagsprog). Eksempler på dette ses ved udtalelser som: "Man bygger hele tiden oven på noget, man ved, og man vil gerne vide, hvad de har lavet der, så bygger man videre" (dansklærer) samt "Jeg prøver hele tiden at tage det ind $\mathrm{i}$ faget [...] nogle gange er det sådan delt op, nu arbejder vi kun med det sådan i lang tid" (matematiklærer). Dette syn på indholdet $\mathrm{i}$ faget adskiller sig fra det enstrengede perspektiv, hvor faget italesættes som bestående af en række færdigheder.

Det er karakteristisk for læreres refleksioner inden for det nuancerede perspektiv, at de føler en stærk forpligtelse på lærerkollegiets beslutninger. De ser sig ind i en social konstellation, der har betydning for deres undervisning, også selvom det er i konflikt med deres eget læringssyn. Her overtrumfer aftaler i lærerkollegiet om bestemte undervisningsformer eller læremidler deres egen lærerfaglighed. Fx stiller en lærer spørgsmål ved den aftalte ugentlige diktat: "Ja, altså fx sådan en som $\mathrm{M}$, han er altid rigtig god på diktatdagen, men spørger man ham en uge senere, har han glemt ordene. Og så er det måske mere udenadslære, altså jeg tror ikke, at man lærer at 
stave af diktat" (dansklærer). En matematiklærer siger om de aftalte test: "Ja, det er lidt åndssvagt, fordi der er mange, der ikke kan løse dem [opgaver] [...] Jeg laver dem, fordi det er noget, vi skal, to gange om året" (matematiklærer). Lærerne er uenige i de fælles beslutninger, men er loyale over for beslutningerne, hvilket understreger forpligtelsen.

Ligesom i deres didaktiske repertoire er der også stor forskel på, hvor stor interesse lærerne udtrykker om deres fag. For en enkelt af lærerne virker det til, at der slet ikke er nogen interesse i faget, og det er svært i interviewet overhovedet at få læreren til at forholde sig til det faglige indhold af den observerede undervisning. På spørgsmålet om, hvad læreren håber, eleverne tager med sig fra danskfaget, svares: "I danskfaget? Altså nok noget med arbejdsdelingen. I danskfaget (tænkepause) at man hjælper hinanden [...] Altså læsestrategier er vigtige. Dem kan de bruge i mange fag. Og så troen på dem selv". Vi ser også lærere, som begrunder faget ud fra en dannelsesorienteret fagdidaktisk forståelse: "Skolen skal vel sammen give eleverne en mulighed for at kunne forholde sig til det, de møder. Det er vel derfor, de lærer matematik, så de kan forholder sig til verden. Så de kan sige hov, kan det nu passe, og det er matematik god til. Hvad betyder det, når politikere siger, at noget falder 50 procent" (matematiklærer). Fælles for alle lærerne er til gengæld, at de har en stærk interesse i at skabe et trygt og rart klasserum: "Jeg prøver at skabe sådan en hyggelig stemning omkring matematikken" (matematiklærer), og da en lærer selv nævner sin meget stramme klasseledelse, og intervieweren spørger ind til observationerne af netop elevernes deltagelse i dansk, svarer læreren: "Ja, i det hele taget for deres trivsel" (dansklærer). Helt overordnet kan man sige, at disse læreres faglige perspektiv handler om, at skolen skal være et rart sted at være, hvor man lærer nogle ting, man nogle gange kan bruge uden for skolen.

Med udgangspunkt i de observerede situationer omkring elever med særlige behov udtrykker lærerne i interviewet, at konteksten har betydning for, at elever med særlige behov får mulighed for læring, og ud fra begrundelser i almendidaktiske arbejdsformer forsøger de at skabe et inkluderende læringsrum. Trods forsøg på fastholdelse i de observerede situationer glider eleverne med særlige behov væk i interviewet, og lærernes inklusionsrefleksionerne bliver generelle. Den enkelte elev synes ikke at være udgangspunktet for deres overvejelser. Når eleverne ser ud til ikke at trives fagligt i det læringsrum, som læreren mener at have tilrettelagt efter et inkluderende fagsyn, så falder lærerne tilbage på et individperspektiv på elevernes læring: “Der er jo nogen, der intuitivt fanger det, og så er der nogen, der har brug 
for at arbejde mere med det. Det er også derfor, jeg siger til dem, der er færdige, at de bare skal arbejde videre. De behøver jo heller ikke at høre efter, når jeg så gennemgår det igen, det ved de godt, så arbejder de bare videre" (matematiklærer). Lærernes manglende refleksioner over det enkelte barns udfordringer synes at stå i vejen for egentlige handlemuligheder.

\section{Det mangefacetterede perspektiv}

Det tredje perspektiv, vi identificerede i vores empiri, er det mangefacetterede lærerperspektiv. Disse lærere er kendetegnet ved at udtrykke en funktionel forståelse af deres fag, hvor faglige elementer skal anvendes og forstås i deres funktion (systematik). Det funktionelle sås hos disse lærere som et genkommende didaktisk mønster i observationerne og blev derfor omdrejningspunkt for interviewene. Udsagn som: "Men der, hvor de opdager, de lærer noget, er, når de anvender det i deres egne produktioner" (dansklærer) var typiske. Lærerne udtrykker skepsis over for, hvad eleverne egentlig lærer af opgaver, som ikke bliver forankret i en selvstændig praksis: "Når du laver nogle funktioner, så er funktioner ikke bare noget, der hedder funktioner, men det er faktisk, fordi nu skal vi på tur [...] At man kan se det, hænger sammen med liv. Det er ikke bare død matematik, der er i en bog" (matematiklærer).

Denne systematik får betydning for lærernes måde at anvende fagsprog og inddrage opgaver og artefakter på (fagsprog/viden), da disse udvælges ud fra kriterier om, at eleverne skal kunne forbinde det faglige indhold med erfaringer og se, hvad de faglige elementer kan anvendes til. Matematiklæreren bruger fx rigtige bonner til at lære eleverne at se logiske mønstre, og dansklæreren arbejder helst med stavning og grammatik i elevernes egne tekster: "Og egentlig kan jeg bedre lide, at når man arbejder med grammatik og staveregler, at man får det ind i torsdagsskrivningen, vi laver, for der er det så på en anden måde et aktiv" (dansklærer).

Lærerne udtrykker også et stort ansvar for skolens fælles beslutninger (social konstellation). Det kan være beslutninger om valg af læremidler, om hvad de skal kunne fra mellemtrinnet til udskolingen, eller strukturelle forhold som et læsebånd hver morgen i alle klasser. De ser altså deres faglighed som en del af en større skolefaglighed, hvor alt, hvad der foregår omkring eleverne, helst skal være et sammenhængende forløb.

Disse lærere har en interesse for faget, som hænger tæt sammen med deres perspektiv. De udtrykker stærkt engagement for deres fag og de muligheder, 
faget kan give eleverne at se og opleve verden med. En matematiklærer siger: "[jeg] prøver at få dem til at opdage, at matematik jo ikke kun er noget med at regne noget ud, men at det også er en måde, man kan beskrive noget på. Og at det bare gør verden en lille smule smukkere, at man faktisk kan opdage nogle ting." Og en dansklærer siger: "Jeg elsker danskfaget. Jeg er virkelig, virkelig glad for danskfaget [...] Det indeholder virkelig så mange facetter".

Lærere i det mangefacetterede perspektiv er forankret i det, som Tetler (2009) betegner som en relationel opfattelse af særlige behov, hvor de er optaget af det enkelte individ og dets læringsforudsætninger, men samtidig ser det i samspil med den konkrete kontekst. Dette kommer til udtryk i interviewet, når vi spørger ind til observerede situationer af elever med særlige behov. En dansklærers udtaler om en elev: "[...] jeg irettesætter ham ikke hele tiden, fordi det er også hele tiden at fortælle ham: "Du har Aspergers, du har Aspergers" [...] han bliver jo spejlet på sin uformåenhed. Og det er ikke godt." Læreren taler her om en observeret situation med en elev, som taler meget grimt, når han er frustreret. Læreren udtrykker opmærksomhed på sin egen, klassens og situationens betydning for elevens frustrationer. Lærerne navigerer mellem forskelligt fagligt indhold, metoder og systematikker i tæt samspil med elevgruppen. Lærerne udtrykker, at de altid tager udgangspunkt i den klasse, de har: "Så det er noget med at få lavet noget, der tager udgangspunkt i de børn, jeg har - hver evig eneste gang" (matematiklærer). Et mønster i observationerne, som dannede baggrund for at tale om elever med særlige behov, viste netop, at lærerne justerede og ændrede tilgangen til den enkelte elev og talte meget med eleverne om deres læringssituation.

Lærerne udtrykker bevidsthed om, at eleverne ikke er i statiske positioner. Lærerne med dette perspektiv ser muligheder for læring hos alle elever og ikke læringsmuligheder som et særligt privilegium hos særlige børn. En matematiklærer siger bl.a.: "Det bliver ligesom, at enten kan man det - og så har man set lyset - eller også er det bare, fordi vi er den slags mennesker, der ikke ser lyset. Enten går vi i kirke, eller også gør vi ikke. Og det er jo slet ikke sådan, det er." Det var netop kendetegnende ved observationerne, at alle elever var i gang, og at læreren henvendte sig til elever, som ikke så aktivt deltagende ud.

Når lærere inden for dette perspektiv begrunder, at de sender elever ud til kompenserende undervisning, er begrundelsen forankret i et funktionelt sigte så som at lære at bruge en it-rygsæk for en dyslektisk elev eller træne 
mundmotorik for en døv elev. Lærerne fortæller, at de søger at støtte elevernes muligheder for tilstedeværelse og deltagelse ved at indføre særlige tiltag, fx pege i stedet for at sige noget for en elev med selektiv mutisme. Eller ved at stille opgaverne på en anden måde for en elev med Aspergers, for eleven: “...kan ikke opfinde historier, vi bliver nødt til at tage udgangspunkt i en film, du har set, og så se, om du kan lave den om" (dansklærer).

\section{Inklusion i fagundervisningen}

Peter Farrell (2004) definerer inklusion som bestående af fire komponenter: tilstedeværelse, accept, aktiv deltagelse og præstation. I denne artikel har vi valgt at anvende Farells forståelse af inklusion, fordi den rummer både en faglig og en social dimension. Artiklen lægger sig dermed op ad nyere inklusionsforskning, der peger på, at inklusion må ses i samspillet mellem faglig og social deltagelse (Schmidt, 2015; Plaugborg, 2011). Farrell (2004) definerer tilstedeværelse, som at eleverne er fysisk til stede i det almenpædagogiske miljø. Accept refererer til, at alle aktører i skolekonteksten også anerkender og accepterer elevernes tilstedeværelse. Aktiv deltagelse henviser til elevernes mulighed for at deltage i læringsfællesskabets aktiviteter, mens præstation indfanger kravet om, at alle elever skal have mulighed for at opnå faglig progression. I forskningsprojektet Inkluderende faglighed, som ligger til grund for artiklen, har vi dog valgt at fokusere på præstation i tæt samspil med lærerens forståelse af fagdidaktik, da undervisning i klassen er centreret omkring fag. Læreren vil være bærer af en fagdidaktisk forståelse, implicit eller eksplicit, som i både planlægningen, gennemførelsen og evalueringen af undervisning har konsekvenser for lærerens valg af metoder, mål, fagligt indhold og materialevalg.

I artiklen har vi præsenteret de tre forskellige lærerperspektiver, som datamaterialet har tilvejebragt: det enstrengede, det nuancerede og det mangefacetterede lærerperspektiv. De tre lærerperspektiver adskiller sig her væsentligt fra hinanden i både deres fagdidaktiske forståelse og deres syn på eleverne. Det enstrengede lærerperspektiv har hovedsageligt én måde at gribe undervisningen an på, og den er præget af færdighedstræning og gentagede øvelser. Det var ikke muligt at finde brud på det fagdidaktiske mønster som baggrund for interviewene. Dette lærerperspektiv ser særlige behov ud fra et individuelt perspektiv, og det var ikke muligt ved inddragelse af observerede situationer med eleverne at få lærerne til at reflektere over egen rolle eller undervisningens rolle i interviewet. 
I forhold til Farells (2004) første inklusionskriterium, tilstedeværelse, er det kun delvist imødekommet i det enstrengede perspektiv, da elever, som ikke møder de faglige krav, bliver sendt ud af fagundervisningen til forskellige former for støtteundervisning. Accept er til stede i det omfang, at eleverne løser opgaverne og deltager på den måde, som er bestemt af læreren, samt i den form for undervisning, som læreren muliggør. Accepten er altså afhængig af, at eleven selv påtager sig ansvaret for sin manglende læring. Deltagelse og faglig præstation er tilsyneladende kun mulige på én måde, og dette giver begrænsede deltagelses- og præstationsmuligheder for eleverne. Lærerens disciplinerende klasseledelse gør, sammen med en meget snæver elevnorm, at mange elever, ikke kun elever med særlige behov, men også særlig fantasifulde eller ivrige elever, har svært ved at blive inkluderet i klassen. Eftersom det faglige og det sociale er så tæt sammenvævet, får elever, der falder uden for den meget snævre elevnorm, meget begrænsede sociale deltagelsesmuligheder.

Det nuancerede lærerperspektiv spænder over flere fagdidaktiske metoder og er bredere funderet i fagdidaktikken. Lærerne synes dog ikke at have blik for, hvornår de fagdidaktiske metoder hæmmer eller fremmer læring. Og når de ser elever med særlige behov, har de tilsyneladende svært ved at reflektere over, hvordan de skal justere undervisningen. På trods af at disse lærere som udgangspunkt udtrykker et relationelt syn på særlige behov, så ser det ud til, at deres begrænsende fagdidaktiske formåen bidrager til, at de kommer til at anlægge et individorienteret syn på særlige behov.

Lærerne i dette perspektiv skaber mulighed for elevernes tilstedeværelse i klassen ved som udgangspunkt at acceptere, at alle eleverne er i klassen. I denne praksis er variationen af almen- og fagdidaktiske metoder så tilpas nuanceret, at deltagelse synes mulig for mange elever. Der er dog en gruppe af elever, for hvem det er svært at deltage, og som det er svært for læreren at finde nye deltagelsesmuligheder for, hvilket kan have en negativ betydning for disse elevers præstation. Lærerens største udfordring ser ud til at dreje sig om løbende justering af undervisningen i den konkrete praksis. I observationer, som dannede baggrund for interviewet, fremstod det som et mønster, at læreren kom til kort, når hun opdagede, at nogle elever ikke magtede den opgave, hun havde sat i værk. Hun holdt typisk fast i sit generelle læringsmål og forsøgte derefter ved vejledning at hjælpe eleverne til at nå det på samme vilkår som resten af klassen. Når eleven ikke kan nå opgaven, springes opgaven over, hvilket flere af lærerne kommer ind på i interviewene. En konsekvens af dette kunne være, at disse elever kommer til at have mange 
ikke færdiggjorte opgaver, fordi de er nødt til at springe videre for at nå i mål. Dette kan igen resultere i manglende faglig præstation og bidrage negativt til elevens selvbillede. Her adskiller det nuancerede lærerperspektiv sig væsentligt fra det mangefacetterede lærerperspektiv, der forudser flere udfordringer i sit didaktiske design og dermed er bedre til at skabe løsninger, inden eleven oplever ikke at slå til.

Det mangefacetterede lærerperspektiv har et stort og bredt fagdidaktisk repertoire, og lærerne er ikke mindst i stand til at justere opgaveløsningerne efter elevernes behov og dagsform. Disse lærere er nysgerrige efter at finde elevernes læringspotentiale og ser elevernes særlige behov ud fra et relationelt perspektiv. Lærerne har det derfor som et grundvilkår, at alle elever selvfølgelig skal være til stede i klassen. Dette grundvilkår medfører, at eleverne bliver accepteret som en del af klassens fællesskab. Læreren modellerer desuden en accepterende adfærd over for elever med særlige behov, som elevgruppen som helhed tager ved lære af. Den store fagdidaktiske variation og evnen til at justere løbende, koblet sammen med respekten for elevernes formåen og den relationelle tilgang til eleverne må antages at resultere i mange deltagelsesmuligheder og dermed større mulighed for faglig præstation. Eftersom elever med særlige behov her ofte kommer i mål med deres arbejde, så opbygges der formentlig mestringsforventninger og positive selvbilleder. Lærerne fortæller, at de oplever, at den mindre frustration, som de skal tage hånd om, også skaber mere ro til at lære; både ro i klassen og ro for den enkelte elev med særlige behov.

Det store spænd mellem de tre lærerperspektiver med hensyn til elever med særlige behov og lærernes fagdidaktiske spændvidde kan datamaterialet ikke forklare. Det kræver yderligere undersøgelser, der kigger specifikt på årsagsforklaringer til dette spænd. Dette studie undersøger primært, hvordan inklusion og fagdidaktik spiller sammen (deskriptivt), og ikke hvorfor det ser ud, som det gør (kausalt). Et nærliggende næste spørgsmål kunne være, hvordan det mangefacetterede lærerperspektiv udvikles og understøttes.

\section{Konklusion}

Sammenhængen mellem inklusion og fagdidaktik er kompleks. Artiklen viser, at der er en sammenhæng mellem lærernes fagdidaktiske repertoire, deres inklusionsperspektiv og elevernes mulighed for accept, tilstedeværelse, deltagelse og præstation. Igennem artiklen har vi vist, hvordan lærere har forskellige perspektiver på inklusion og fagdidaktik, hvilket potentielt 
medfører meget forskellige deltagelsesmuligheder for eleverne. Det gælder ikke kun for elever med særlige behov, men alle elever.

Artiklen peger på, at de lærere, der tilsyneladende lykkes bedst med at håndtere elever med særlige behov, er de lærere, som ikke kun udtrykker stor faglig viden, men også udtrykker stort fagdidaktisk repertoire. Mængden af fagdidaktiske metoder er ikke ligegyldig, da det er forudsætningen for, at lærerne evner at justere undervisningen løbende i mødet med elever med særlige behov.

Det kan synes lidt banalt, at det er de lærere med størst fagdidaktisk faglighed, der bedst håndterer inklusion, men artiklen nuancerer dette ved at vise, hvilke refleksioner der ligger til grund. De er gode til at justere og omforme, således at eleverne får mulighed for at deltage og udvikle sig fagligt og dermed blive en del af læringsfællesskabet i klassen. Derudover ser det også ud til, at evnen til fagdidaktisk justering er helt afgørende for, hvordan lærerne kan se børn med særlige behov. Kommer læreren til kort fagdidaktisk, er det tilsyneladende svært at bevare det relationelle perspektiv på inklusion, også selv om lærerne som udgangspunkt omtaler undervisningen og eleverne ud fra et relationelt perspektiv og rigtig gerne ville se eleverne i den sociale kontekst.

Det peger på, at der ligger en stor opgave foran os til yderligere at få undersøgt sammentænkningen af fagdidaktik og inklusion. Lærerne, læremidler, læreruddannelse, efter- og videreuddannelse og forskning har en kæmpe opgave i at udvikle dette felt, og ledelsen på skolerne har en vigtig opgave med at anerkende det, som det mangefacetterede lærerperspektiv kan, og med at facilitere arbejdet med inklusion som en situeret praksis med præcis den elevgruppe og det fag, lærerne har.

\section{Referencer}

Adler, B. (2005). Vad är dyskalkyli? En bok om matematiksvårigheter. NU-förlaget.

Albrechtsen, T.R.S. (2016). Professionelle læringsfællesskaber - teamsamarbejde og undervisningsudvikling. Dafolo.

Alenkær, R. (2010). Arbejdet med adfærd, kontakt og trivsel - $i$ en inkluderende skole. Ph.d.-afhandling. Syddansk Universitet.

Amilon, A. (red.)(2015). Inkluderende skolemiljøer: Elevernes roller. SFI - Det Nationale Forskningscenter for Velfærd.

Askew, M., Brown, M., Rhodes, V., Wiliam, D., \& Johnson, D. (1997). Effective Teachers of Numeracy: Report of a study carried out for the Teacher Training Agency. King's College, University of London. http://www.leeds.ac.uk/educol/documents/000000385.htm 
Ball, D.L., Thames, M.H., \& Phelps, G. (2008). Content Knowledge for Teaching: What makes it special? Journal of Teacher Education, 59(5), 389-407. https://doi. org/10.1177\%2F0022487108324554

Bremer, J., Bundsgaard, J., Fougt, S.S., \& Skyggebjerg, A.K. (2017). Læremidlernes danskfag. Aarhus Universitetsforlag.

Bundsgaard, J., \& Fougt, S.S. (2017). Faglighed og scenariedidaktik. I: Hanghøj, T., Misfelt, M., Bundsgaard, J., Fougt, S.S., \& Hetmar, V. (red.), Hvad er scenariedidaktik? Aarhus Universitetsforlag.

Butterworth, B. (2003). Dyscalculia Screener. NFER-Nelson. http://discovery.ucl.ac.uk/id/ eprint/91016

Den Danske Regering (2013). Aftale mellem regeringen (Socialdemokraterne, Radikale Venstre og Socialistisk Folkeparti), Venstre og Dansk Folkeparti om et fagligt løft af folkeskolen. Undervisningsministeriet.

Dreyfus H., \&Dreyfus, S. (1986). Mind over machine. The power of human intuition and expertise in the era of the computer. The Free Press.

Dyssegaard, C. (2009). Inkluderende pædagogik: intentioner og virkelighedens verden: et mixed methods forskningsprojekt. Ph.d.-afhandling. DPU, Aarhus Universitet.

Emtoft, L.E. (2017). "Jeg har aldrig prøvet at være den første før" - en undersøgelse af lærere og elevers praksis med IT og dennes betydning for deltagelse og inklusion. Ph.d.-afhandling. Roskilde Universitet.

Engsig, T.T. (2016). Inkluderende støtteforanstaltninger i folkeskolens almenundervisning. En undersøgelse af støtteforanstaltningers betydning for elevers deltagelsesmuligheder, læring og oplevelse af inklusion. Ph.d.-afhandling. Aalborg Universitetsforlag.

Engström, A. (2003). Specialpedagogiska frågeställningar i matematik, en introduktion. Arbetsrapporter vid Pedagogiska institutionen, 8. Örebro Universitet. http://kau.diva-portal. org/smash/record.jsf?pid=diva2\%3A845486\&dswid=441

Ernest, P. (2000). Why teach mathematics? I: Bramall, S., \& White, J. (red.), Why Learn Maths? (s. 1-14). Bedford Way Papers.

Geary, D.C. (2004). Mathematics and learning disabilities. Journal of learning disabilities, 37, 4-15. https://doi.org/10.1177/00222194040370010201

Gellert, A.S., Poulsen, M., \& Elbro, C. (2018). Ordblindhed. Samfundsøkonomen, (1), 22-24.

Grimsæth, G., \& Holgersen, H. (2015). Nyutdannede allmennlærere og deres opplevelse av faglig kompetanse i leseopplæring generelt og av elever med lesevansker spesielt. Acta Didactica Norge - nasjonalt tidsskrift for fagdidaktisk forsknings- og utviklingsarbeid, 9(1), 1-17. http://dx.doi.org/10.5617/adno.2368

Halkier, B., \& Jensen, I. (2008). Det sociale som performativitet. Dansk sociologi, 3(19), 49-68.

Hansen, J.J. (2012) Dansk som undervisningsfag. Perspektiver på didaktik og design. Dansklærerforeningens Forlag.

Hansen, T.I. (2015). Dansk. Forlaget Klim.

Hedegaard-Sørensen, L., \& Grumløse, S.P. (2016). Lærerfaglighed, inklusion og differentiering. Pxdagogiske lektionsstudier. Samfundslitteratur.

Jørgensen, A., Blankenberg, M., Skall, U., \& Schjerbeck, R. (2016). Afrapportering af inklusionseftersynet - Den samlede afrapportering. Ministeriet for Børn, Undervisning og Ligestilling. https://viden.sl.dk/artikler/boern-og-unge/socialt-udsatte/afrapportering-af-inklusionseftersynet-et-overblik-over-den-samlede-afrapportering/

Kampmann, J. (2017) Interview med børn. Hans Reitzels Forlag.

Knudsen, R.K., Lindberg, S., \& Kampmann, J. (2009). Erfaringer med børneinterview i forskningssammenhæng. 5. delrapport fra Følgeforskningen omkring Fri For Mobberi. Center i Barndoms- og Ungdomsforskning, Roskilde Universitetscenter. 
Kofoed, J. (2003). Elevpli: inklusion - eksklusionsprocesser blandt børn i skolen. Ph.d.-afhandling. DPU, Aarhus Universitet.

Laursen, H.P. (2011). Lukket inde i et alt for lille alfabet. Nordand - Nordisk tidsskrift for andrespråksforskning, 6(2), 35-58.

Lerman, S. (2002). Situating Research on Mathematics Teachers' Beliefs and on Change. I: Leder, G.C., Pehkonen, E., \& Törner, G. (red.), Beliefs: A Hidden Variable in Mathematics Education. Kluwer Academic Publishers. https://doi.org/10.1007/0-306-47958-3_14

Llinares, S. (2002). Participation and Reification in Learning to Teach: The Role of Knowledge and Beliefs. I: Leder, G.C., Pehkonen, E., \& Törner, G. (red.), Beliefs: A Hidden Variable in Mathematics Education. Kluwer Academic Publishers. https://link.springer.com/ chapter/10.1007/0-306-47958-3_12

Lloyd, G.M. (2002). Mathematics Teachers' Beliefs and Experiences with Innovative Curriculum Materials. The Role of Curriculum in Teacher Development. I: Leder, G.C., Pehkonen, E., \& Törner, G. (red.), Beliefs: A Hidden Variable in Mathematics Education. Kluwer Academic Publishers. https://doi.org/10.3126/sj.v8i0.18458

Lunde, O. (2010). Nu fär jeg det til.... Om tilpasset læring i matematik. Special-pædagogisk Forlag.

Madsen, U.A. (2003). Pædagogisk etnografi. Forlaget Klim.

Madsen, J., \& Nielsen, L.O. (2018). Situeret fremstilling. Samfundslitteratur.

Molbæk, M. (2016). Inkluderende klasse-og læringsledelse. DPU, Aarhus Universitet.

Ostad, S.A. (2008). Children With and Without Mathematics Difficulties-7: Aspects of Learner Characteristics in a Developmental Perspective. Mathematical Difficulties. Elsevier. http://dx.doi.org/10.1016/B978-012373629-1.50009-5

Plauborg, H. (2011). Klasseledelse og fællesskabende didaktikker: om meningsfulde læringsmuligheder og værdig deltagelse i undervisningen. Kvan - et tidsskrift for læreruddannelsen og folkeskolen, 31(90), 67-78.

Quvang, C. (2009). Jeg vil hellere have været $i$ den anden båd - Narrativer om specialundervisning - på sporet af læring, identitet og livsduelighed: En "fortælling" om specialpædagogikkens betydning for, hvordan tilværelsen kan opleves. Syddansk Universitet, Det Humanistiske Fakultet.

Ratner, H. (2012). Promises of reflexivity - Managing and researching inclusive Schools. Ph.d.-afhandling. Copenhagen Business School.

Rowland, T., Huckstep, P., \& Thwaites, A. (2005). Elementary Teachers' Mathematics Subject Knowledge: The Knowledge Quartet and the Case of Naomi. Journal of Mathematics Teacher Education, 8(3), 255-281. https://doi.org/10.1007/s10857-005-0853-5

Schmidt, M.C.S. (2015). Inklusionsbestræbelser i matematikundervisningen: En empirisk undersøgelse af matematiklæreres klasseledelse og elevers deltagelsesstrategier i folkeskolen. Ph.d.-afhandling. DPU, Aarhus Universitet.

Shulman, L.S. (1986). Those Who Understand: Knowledge Growth in Teaching. Educational Researcher, 15(2), 4-14. https://doi.org/10.3102\%2F0013189X015002004

Sjöberg, G. (2006). Om det inte är dyskalkyli - vad är det då? En multimetodestudie av eleven $i$ matematikproblem ur ett longitudinellt perspektiv. Doktoravhandling i Pedagogiskt arbete Nr. 7. Umeå Universitet. https://www.skolporten.se/forskning/avhandling/om-det-inte-ar-dyskalkyli-vad-ar-det-da-bren-multimetodstudie-av-eleven-i-matematikproblem-ur-ett-longitudinellt-perspektiv/

Svendsen, H. (2016). Teknologibaseret læsning og skrivning i folkeskolen. Ph.d.-afhandling. DPU, Aarhus Universitet.

Svendsen, H. (2017). Inklusion i et læsevanskelighedsperspektiv. Specialpædagogik, 37(3/4), 98-105.

Tetler, S. (2000). Den inkluderende skole - fra vision til virkelighed. Gyldendal. 
Tetler, S. (2009). Specialpædagogiske perspektiver og deres konsekvens for praksis. I: Tetler, S. \& Langager, S. (red.), Specialpædagogik i skolen: En grundbog (s. 25-34). Gyldendal.

Undervisningsministeriet (2012). Lov om ændring af lov om folkeskolen, lov om friskoler og private grundskoler m.v. og lov om folkehøjskoler, efterskoler, husholdningsskoler og håndarbejdsskoler (frie kostskoler) Lov nr. 379 af 28/04/2012. Undervisningsministeriet.

White, M. (2006). Narrativ teori. Hans Reitzels Forlag.

Wilson, M., \& Cooney, T. J (2002). Mathematics Teacher Change and Development. The Role of Beliefs. I: Leder, G.C., Pehkonen, E., \& Törner, G. (red.), Beliefs: A Hidden Variable in Mathematics Education. Kluwer Academic Publishers. http://dx.doi.org/10.1007/0-30647958-3_8 